\title{
POTENSI SUMBER DAYA AIR DI KOTA DAN KABUPATEN SORONG
}

\author{
Tirsa Fajrin Mochtar ${ }^{1)}$, Agung pamudjianto ${ }^{2)}$ \\ ${ }^{1)}$ Program Studi Teknik Sipil Universitas Muhammadiyah Sorong \\ Jalan Pendidikan No 27 Kota Sorong, Propinsi Papua Barat Email \\ :ctirsactirsa@gmail.com
}

\begin{abstract}
ABSTRAK
Kota Sorong adalah salah satu daerah di Provinsi Papua Barat. Kota Sorong terletak di Semenanjung Kepala Burung pulau Papua. Secara geografis kota Sorong berada pada koordinat $131^{\circ} 51^{\prime} \mathrm{BT}$ dan $0^{\circ} 54^{\prime} \mathrm{LS}$ dengan luas wilayah $1.105 \mathrm{~km} 2$, Di Provinsi Papua Barat terdapat beberapa sumber daya air yang sebagian besar sumber daya air nya yang terbentuk adalah pada kabupaten-kabupaten di wilayah pengembangan Sorong, Tujuan peneltitian ini adalah untuk menganalisa potensi sumber daya air di kota dan kabupaten sorong. Potensi sumber daya air di Kota dan Kabupaten Sorong yang teridentifikasi adalah terpadu, dan berwawasan lingkungan hidup dengan tujuan mewujudkan kemanfaatan sumber daya air yang berkelanjutan, Agar Besarnya jumlah air yang tercatat pada meter air pelanggan, diasumsikan merupakan kemampuan layanan sistem distribusi air bersih, untuk melihat tingkat kebutuhan penggunaan air bersih masyarakat.
\end{abstract}

Kata Kunci : sumber daya air, Kota dan Kabupaten Sorong 


\section{PENDAHULUAN}

Provinsi Papua Barat secara astronomis terletak pada $24^{\circ}-132^{\circ}$ Bujur Timur dan $0^{\circ}-4^{\circ}$ Lintang Selatan, tepat berada di bawah garis khatulistiwa dengan ketinggian 0-100 meter dari permukaan laut. Wilayah Provinsi Papua Barat terdiri dari 7,95\% merupakan puncak gunung, $18,73 \%$ berada di lembah. Wilayah lain lebih dari separuhnya berada di daerah hamparan. Seluruh wilayah kabupaten/kota di Papua Barat berbatasan dengan laut, namun hanya 37,04\% desa yang berada di daerah pesisir. Wilayah desa lainnya tidak berbatasan dengan laut (bukan pesisir), yaitu sebesar 62,96\%. Sumber Daya Air di Kota Sorong dan Kabupaten sorong harus mengacu pada UU no 7 tahun 2004 dan PP No 42 tahun 2008 tentang Sumber Daya Air dimana prinsip keberlanjutan dalam pengelolaan menjadi faktor yang penting.sehingga ketersediaan air bersih bagi masyarakat dapat terpenuhi. sumber air yang ada pada kota maupun kabupaten sorong salah satunya adalah sumber daya air dalam pengelolaan danau mempunyai fungsi utama adalah untuk menstabilkan aliran air, dan di lain sisi danau juga mempunyai fungsi ekonomi yang sangat tinggi, yaitu untuk penyediaan air bersih, baik untuk minum,irigasi, dan industri, juga untuk perikanan budidaya maupun perikanan tangkap. Jika dikelola dengan benar, maka danau akan berfungsi secara optimal sebagai penyangga kehidupan. Penjagaan kuantitas dan kualitas air danau diharapkan dapat menjamin ketersediaan air baku sepanjang daerah alirannya. Masalah yang dihadapi dalam pengelolaan danau adalah pada bagaimana analisa potensi ketersediaan dan pemanfaatan air danau sebagai sumber air irigasi.

\section{METODE}

\section{Lokasi studi}

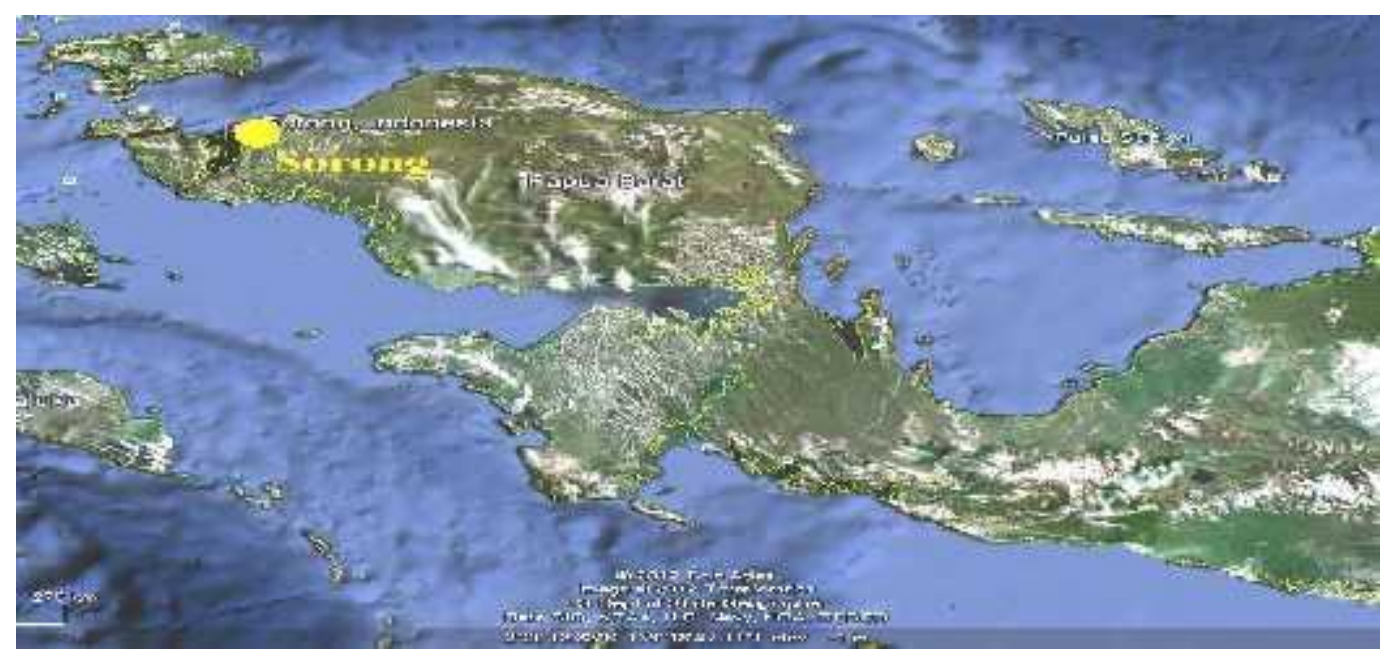

Gambar 1. Lokasi studi

\section{Tahap penyusunan artikel}

1. Penentuan tema

2. Penelusuran artikel yang bersesuaian dengan tema yang di ambil ( melalui google scholar)

3. Analisa komparatif terhadap artikel yang di dapatkan dari google scholar.

4. Membuat kesimpulan untuk menjawab tujuan penulis. 
Semua metode penulisan dan analisa dalam artikel ilmiah ini merujuk pada panduan penulisan tugas akhir Fakultas Teknik Universitas Muhammadiyah Sorong tahun 2014 (Pristianto, Amri, \& Rusdi, 2014).

\section{HASIL DAN PEMBAHASAN}

Penelitian dengan tema yang sama

Beberapa hasil penelitian terkait tema artikel ini adalah sebagai berikut:

1. Menurut Pristianto (2018) yang meneliti Pengelolaan Sumber Daya Air Yang

Berkelanjutan di Kota Sorong, maka kesimpulan yang dapat di ambil dari uraian ini, khususnya dan di Indonesia adalah :

a. sesuai dengan amanat UU No 7 / 2004 dan PP no 42 / 2008 tentang Sumber Daya Air

b. harus mengacu pada program IWRM, pengembangan AGRO KONSERVASI,River Restoration, Water Harvesting Management in Upland, pengkajian Retrding Bazin, Pengkajian mitigasi Bencana dengan Analisis Spasial Banjir dan Karakteristik Fisiografi, Wastewater dan Water Treatment Technology.

2. Menurut Fonda (2012) yang meneliti tinjauan system jaringan distribusi dan tingkat kebutuhan penggunaan air bersih di distrik aimas kabupaten sorong, maka kesimpulan yang dapat di ambil dari uraian ini adalah :

a. Besarnya jumlah air yang tercatat pada meter air pelanggan , diasumsikan merupakan kemampuan layanan sistem distribusi air bersih , untuk melihat tingkat kebutuhan penggunaan air bersih masyarakat .

b. Parameter tekanan air dan kontinuitas aliran merupakan factor penunjang dalam melengkapi hasil analisa terhadap indicator unjuk kerja jaringan sistem distribusi air bersih terhadap parameter debit aliran air .

c. Kuantitas air bersih yang dimaksud yaitu terpenuhinya kebutuhan setiap pelanggan, yang dalam penelitian ini adalah warga, kontinuitas aliran air bersih yang di maksud adalah tercukupinya pasokan air bersih sesuai dengan kebutuhan pelanggan ,dan mengalir secara kontinyu 24 jam setiap hari .

3. Menurut Herman (2017) yang meneliti peningkatn sistem jaringan distribusi guna pelayanan air bersih di distrik sorong timur kota sorong, maka kesimpulan yang dapat di ambil dari uraian ini adalah :

a. Kebutuhan air bersih untuk distrik sorong timur sampai tahun 2030 mencapai 122 ltr/det. Dan debit air baku dari sungai warsamson berdasarkan hasil pengukuran langsung di lapangan yang dilakukan oleh pihak PT. TIRTA REMU dan pihak WMD pada tanggal 27 oktober 2009 , yang mana pada saat itu terjadi musim kemarau selama hamper \pm 2 bulan adalah \pm $3.000 \mathrm{ltr} /$ det. Dengan memanfaatkan air baku dari sungai warsamson 3.000ltr/det. Sudah dapat memenuhi kebutuhan air penduduk distrik sorong timur .

b. Direncanakan system perencanaan air bersih dengan cara dual sistem, yaitu dengan cara pompa dan gravitasi . yang mana pemompaan di gunakan untuk memompa air baku dari sungai menuju unit pengolahan, hal ini di sebabkan karena lokasi air baku lebih rendah dari lokasi unit pengolahan, dan dari unit pengolahan menuju reservoir distribusi air dilahirkansecaragravitsi. 
c. Sistem pelayanan air bersih yang di buat ini terdiri dari intake, pompa, pipa transmisi , unit pengolahan, reservoir penampang, pipa distribusi , reservoir distribusi , dan hidran umum.

Analisa

1. Potensi Sumber daya air harus sesuai dengan amanat Undang Undang No. 7 tahun 2004 harus dikelola secara menyeluruh, terpadu, dan berwawasan lingkungan hidup dengan tujuan mewujudkan kemanfaatan sumber daya air yang berkelanjutan. Pengelolaan sumber daya air harus dilakukan berbasis wilayah sungai. sehingga dapat memenuhi kebutuhan masyarakat dan lingkungan . harus mengacu pada program IWRM, pengembangan AGRO KONSERVASI, River Restoration, Water Harvesting Management in Upland, pengkajian Retrding Bazin, Pengkajian mitigasi Bencana dengan Analisis Spasial Banjir dan Karakteristik Fisiografi, Wastewater dan Water Treatment Technology.

2. Agar Besarnya jumlah air yang tercatat pada meter air pelanggan, diasumsikan merupakan kemampuan layanan sistem distribusi air bersih , untuk melihat tingkat kebutuhan penggunaan air bersih masyarakat . dalam melengkapi hasil analisa terhadap indicator unjuk kerja jaringan sistem distribusi air bersih terhadap parameter debit aliran air.

3. Ketersediaan air bersih dilakukan oleh pihak PT. TIRTA REMU dan pihak WMD, Sistem pelayanan air bersih yang di buat ini terdiri dari intake, pompa , pipa transmisi , unit pengolahan , reservoir penampang, pipa distribusi , reservoir distribusi, dan hidran umum.

4. Sumber daya air merupakan kebutuhan berdasar bagi kebutuhan manusia, hewan , tumbuhan . ketersediaan sumber daya air harus selalu tersedia namun harus dalam jumlah yang cukup memadai .

\section{KESIMPULAN}

Potensi sumber daya air di Kota dan Kabupaten Sorong yang teridentifikasi adalah terpadu, dan berwawasan lingkungan hidup dengan tujuan mewujudkan kemanfaatan sumber daya air yang berkelanjutan, Agar Besarnya jumlah air yang tercatat pada meter air pelanggan , diasumsikan merupakan kemampuan layanan sistem distribusi air bersih , untuk melihat tingkat kebutuhan penggunaan air bersih masyarakat.

\section{DAFTAR PUSTAKA}

1. Pristianto, H. (2018). Pengelolaan Sumber Daya Air Yang Berkelanjutan Di Kota Sorong.

2. Fonda , R. N. H. (2012) Tinjauan sistem jaringan distribusi dan tingkat kebutuhan penggunaan air bersih di distrik aimas kabupaten sorong .

3. 3.Herman , (2017) Peningkatan sistem jaringan distribusi guna pelayanan air bersih di distrik sorong timur kota sorong

4. Pamudjianto, A., \& Sutiono, W. (2018). Pemanfaatan Air Danau Sebagai Sumber Air Untuk Irigasi.

5. Pristianto, H., Amri, I., \& Rusdi, A. (2018). Pedoman Penulisan Tugas Akhir Fakultas Teknik Universitas Muhammadiyah Sorong. 